\title{
Temporal expression of the sor1 gene and inhibitory effects of Sorghum bicolor L. Moench on three weed species
}

Roseane Cavalcanti dos Santos ${ }^{1}$, Gabriela de Morais Guerra Ferraz ${ }^{2}$, Manoel Bandeira de Albuquerque Liziane Maria de Lima ${ }^{1}$, Péricles de Albuquerque Melo Filho ${ }^{2}$ and Alessandra de Rezende Ramos ${ }^{4}$

Received: June 21, 2013. Accepted: January 30, 2014

\begin{abstract}
The temporal expression of gene sor 1 and the inhibitory effect of Sorghum bicolor L. Moench against weeds were studied by semiquantitative polymerase chain reaction and intercropping management, respectively. To quantify sor 1 expression, seeds were sown in pots and RNA was collected from the roots at 5, 10,15,20 and 30 days after emergence (DAE). In the inhibition assay, cotton and three weeds were evaluated during single cropping and during intercropping with S. bicolor. The assay was completely randomized, with eight replications. We found early expression of sor 1 in most $S$. bicolor accessions by $5 \mathrm{DAE}$, and a gradual reduction thereafter. Only one of the accessions showed sor 1 expression up to $30 \mathrm{DAE}$. In the inhibition assay, the most significant effects were related to the dry matter production (shoots and roots) of the weeds Cenchrus echinatus and Cynodon dactylon. The intercropping of cotton and S. bicolor had no apparent deleterious effects.
\end{abstract}

Key words: Allelopathy, semiquantitative PCR, sorgoleone, weeds

\section{Introduction}

Weeds are a serious problem in all kinds of crops, because they affect the development cycle and yield, especially in herbaceous species before flowering. Although various control methods are available, the most effective is the use of synthetic herbicides, which unfortunately have high costs in terms of management, as well as posing risks to human health and the environment (Bolonhezi et al. 2005; Cheema et al. 2003). The use of such herbicides in a single-cropping system can also lead to further selection of herbicide-resistant weeds (Neves 2005).

Despite the numerous benefits that classical breeding has brought to crop yields, it is still limited in its capacity to generate weed-resistant cultivars. In contrast, the current techniques, which are based on the use of biotechnology-derived herbicide-resistant crops, have contributed to minimizing the use of herbicides, thereby providing greater crop protection and productivity (Parker et al. 2005; Correia \& Durigan 2007; Imura et al. 2011). However, the management of such crops can still require the use of chemical herbicides.

Weed control through the use of natural defensive agents obtained from other plants is an agroecological alternative often adopted by farmers of small plots of land (less than $10 \mathrm{ha}$ ). In general, a solution containing extracts from several herbicide species is sprayed weekly between rows of short-cycle crops, such as beans, corn, cotton and peanuts (Melo et al. 2013). In the literature, several studies have demonstrated the potential of allelopathic herbicides, at low concentration, to control monocot and dicot weeds (Bertin et al. 2003; Weston \& Duke 2003; Albuquerque et al. 2010). This practice is beneficial to the environment and offers the potential for biorational weed control. It can also minimize the cost of management, given that many of the herbicide species are widely distributed on croplands.

According to Souza Filho et al. (2006), allelochemicals produced by plants affect local vegetation and the succession of others plants, as well as playing a role in the induction of dormancy and seed preservation. Such chemicals therefore constitute an important mediator of population dynamics because they determine the pattern and density of vegetation, in natural and crop systems alike. Numerous plants have been reported to be allelopathic, including lichens, alfalfa, cucumber, rye, barley, wheat, rice, soybeans, and sorghum (Singh et al. 2003; Belz 2007; Albuquerque et al. 2010).

Sorghum bicolor L. Moench is an important food crop for farmers working land within semi-arid environments. It is also an allelopathic species that represses the growth

\footnotetext{
${ }^{1}$ Embrapa Algodão, Laboratório de Biotecnologia, Campina Grande, PB, Brasil

${ }^{2}$ Universidade Maurício de Nassau, Recife, PE, Brasil

${ }^{3}$ Universidade Federal da Paraíba, Centro de Ciências Agrárias, Areia, PB, Brasil

${ }^{4}$ Universidade Federal do Sul e Sudeste do Pará; Instituto de Estudos em Saúde e Biológicas, Faculdade de Biologia, Marabá, PA, Brasil

${ }^{5}$ Author for correspondence: roseane.santos@embrapa.br
} 
Roseane Cavalcanti dos Santos, Gabriela de Morais Guerra Ferraz, Manoel Bandeira de Albuquerque,

Liziane Maria Lima, Péricles de Albuquerque Melo Filho and Alessandra de Rezende Ramos

of numerous weeds, mainly the small-seeded species, due to exudates released by its roots, those exudates consisting mainly of sorgoleone, a biologically active lipid benzoquinone (Forney \& Foy 1985; Netzly \& Butler 1986; Meazza et al. 2002; Dayan et al. 2007; Marchi et al. 2008; Albuquerque et al. 2010). Sorgoleone (2-hydroxy-5-methoxy3-[(8'Z,11'Z)-8',11',14'-pentadecatriene]-p-benzoquinone) is highly phytotoxic to broad-leaf and grass weeds at concentrations as low as $10 \mu \mathrm{M}$, affecting shoot growth with little or no effect on root growth (Einhellig \& Souza 1992; Nimbal et al. 1996; Czarnota et al. 2001). The most active ingredients of sorgoleone reside in the 1,4-hydroquinone portion, which constitutively releases $\sim 80-95 \%$ of the molecule (Dayan et al. 2007; Albuquerque et al. 2010). Depending on the genotype, the expression of sorgoleone will have a greater or lesser potential to inhibit germination of the surrounding plants, particularly broad-leaf and grass weeds, at low concentrations (Yang et al. 2004).

According Meazza et al. (2002) and Hejl \& Koster (2004), the role of sorgoleone as a natural herbicide is due to its effect on electron transport in the chloroplasts, whereby it inhibits the production of $p$-hydroxyphenylpyruvate dioxygenase (HPPD) in a manner similar to that of synthetic herbicides. Inhibition of HPPD disrupts the biosynthesis of carotenoids and results in the bleaching of leaves, due to a loss of chlorophyll. In the field, sorgoleone has an inhibitory effect on the growth of several species, including beans, wheat, and soy, although its greatest effect has been shown to be on the growth of weeds (Roth et al. 2000; Souza Filho et al. 2006). Sorgoleone is biosynthesized, during early seedling establishment, by root hairs, which possess the entire metabolic machinery (Dayan 2006; Baerson et al. 2008a, 2008b). According to Marchi et al. (2008), sorgoleone is rapidly degraded in soil and is mainly produced in younger plants, its production peaking by 10 days after emergence (DAE). However, other authors have reported that sorgoleone has a long half-life in the soil, with long-term effects on many cellular targets (Dayan et al. 2007; Baerson et al. 2008a, 2008b; Barbosa et al. 2010).

Molecular studies have described the metabolic pathway of sorgoleone, and a number of genes involved in the event cascade have been identified and characterized (Buchanan et al. 2000; Dayan et al. 2003; Pan et al. 2007; Baerson et al. 2008a, 2008b). According to Dayan et al. (2003), the gene sor1, which encodes a membrane desaturase, is the main precursor of sorgoleone synthesis.

Although the cellular localization and the steps of the biosynthetic pathway of sorgoleone have been determined (Dayan et al. 2003; Pan et al. 2007; Baerson et al. 2008a, 2008 b), there is a lack of studies investigating its differential expression among genotypes and its bioactivity in vivo. Therefore, the evaluation of accessions that show variability for sorgoleone synthesis could contribute to the selection of the top lines in breeding programs for food production, as well as for weed control, in farming systems.
In the present study, we evaluated the temporal expression of sor1 in Sorghum accessions. We also quantified its inhibitory effect in an intercropping system with three herbaceous weeds.

\section{Material and methods}

\section{Experimental procedure and RNA extraction}

Seeds of five Sorghum bicolor accessions, one each of the cultivars IPA 467-4-2, IPA 7301011, IPA 4202, CNB 9040, and Sudan, were sown in the greenhouse of the Department of Agronomy of the Federal Rural University of Pernambuco, in 5-L pots containing commercial substrate (Plantmax; Eucatex, São Paulo, Brazil). At 5, 10, 15, 20, 30 and 50 DAE, rootlets were collected for RNA extraction (Plant RNA Mini-Spin Invisorb kit; Invitec, Berlin, Germany) from fresh tissue samples $(100 \mathrm{mg})$, in accordance with the manufacturer's recommendations. The concentration and purity of the RNA were estimated with a spectrophotometer (BioPhotometer Plus; Eppendorf, Hamburg, Germany).

\section{CDNA synthesis and semiquantitative polymerase chain reaction}

We synthesized cDNA using a Super SMART PCR cDNA Synthesis Kit (Clontech, Palo Alto, CA, USA), in accordance with the manufacturer's recommendations, using $1 \mu \mathrm{g}$ of RNA from each accession, at different root ages. Specific sor 1 primers (Genbank, EF206348.1) were used in order to perform a $25-\mu \mathrm{l}$ reverse-transcriptase polymerase chain reaction (RT-PCR), as follows: $1 \mu$ l of each cDNA; 2.5 $\mu \mathrm{l}(2 \mathrm{mM})$ of each forward primer (5' TGCCTCCTCGCGCAAAGAAG 3') and reverse primer (5' GGTATAACAACAATGCTCCT 3'); $0.2 \mu$ of Taq polymerase (5 U/ $\mu \mathrm{l}) ; 0.5$ $\mu \mathrm{l}(10 \mathrm{mM})$ of a deoxynucleoside triphosphate set; $2.0 \mu \mathrm{l}$ (25 mM) of $\mathrm{MgCl}_{2}$; and $2.5 \mu \mathrm{l}$ of $10 \mathrm{X}$ buffer. The thermal conditions, achieved with a thermal cycler (Mastercycler Gradient; Eppendorf), were as follows: pre-denaturation at $95^{\circ} \mathrm{C}$ for $5 \mathrm{~min} ; 35$ cycles of denaturation at $95^{\circ} \mathrm{C}$ for 60 $\mathrm{s}$; annealing at $56^{\circ} \mathrm{C}$ for $60 \mathrm{~s}$; and extension at $72^{\circ} \mathrm{C}$ for 60 s. A final extension step, at $72^{\circ} \mathrm{C}$ for $10 \mathrm{~min}$, was added. The products of the reactions (690 bp) were analyzed on an agarose gel $(0.8 \%)$ with a $1-\mathrm{kb}$ DNA ladder (Plus DNA Ladder; Invitrogen, Carlsbad, CA, USA). As a constitutive control, another reaction was performed with $\beta$-actin primers (forward: 5' GATCTGGCATCACACCTTC 3'; and reverse: 5’ AGGAAGCTCGTAGCTCTT 3', 570 bp).

In vivo effect of Sorghum bicolor density on the growth of weeds and cotton

We performed the in vivo inhibition assay in a greenhouse, using the Sorghum bicolor accession that showed the highest sor 1 expression in the semiquantitative RT-PCR. 
We first evaluated the effect of S. bicolor on the weeds Cyperus rotundus, Cynodon dactylon, and Cenchrus echinatus. Plastic pots (17 $\mathrm{cm}$ in diameter) were filled with organic substrate (Plantmax; Eucatex), plus $\mathrm{N}_{2} \mathrm{P}_{2} \mathrm{O}_{5}: \mathrm{K}_{2} \mathrm{O}$ fertilizer (20:10:20). On the basis of the work carried out by Trezzi \& Vidal (2004), we planted a total of nine plants in each pot, at the following weed-S. bicolor ratios: 9:0, 5:4 and 0:9. To investigate the possible allelopathic effect of $S$. bicolor on cotton, we added an arrangement of $S$. bicolor and cotton (Gossypium hirsutum L., cv. CNPA 8H), in pots filled with the same substrate plus $\mathrm{N}: \mathrm{P} 2 \mathrm{O} 5: \mathrm{K} 2 \mathrm{O}$-fertilizer (60:60:60), at sorghum-cotton plant ratios of 9:0, 7:2, and 0:2. The experimental design adopted was totally randomized, with eight replications. Pots were watered daily. Each individual plant height $(\mathrm{cm})$ and dry biomass $(\mathrm{g})$ were measured at 56 days. Statistical analysis were performed with the GENES program (Cruz 2006).

\section{Results and discussion}

The semiquantitative expressions of sor 1 and $\beta$-actin in Sorghum bicolor accessions are shown in Fig. 1. The expression profile of sor 1 differed among accessions, as well as among roots of different ages. In general, the expression of sor1 was highest during the first $20 \mathrm{DAE}$, varying among accessions and trending downward. We observed sor 1 expression as early as 5 DAE, except in the IPA 4202 cultivar (Fig. 1), from which the gene was absent at that stage.

The best sor 1 expression was seen in the Sudan and IPA 7301011 cultivars, the latter distinguished by expression that was more uniform and prolonged, being detectable at up to $30 \mathrm{DAE}$ (Fig. 1). This result is interesting because the longer duration of the sor 1 activity might translate to more effective control of the surrounding weeds, especially in denser cropping. Another aspect is that, in a Sorghum bicolor improvement program, hybridization between the Sudan and IPA 7301011 cultivars could result in high-sorgoleone progenies, prolonging the effects and consequently improving protection against various weeds. Because sor 1 expression was observed at 30 DAE in the Sudan and IPA 4202 cultivars, we also investigated sor 1 expression in both at $50 \mathrm{DAE}$; however, no activity was found. On the basis of those results, the Sudan cultivar was selected for the in vivo assay involving S. bicolor density with weeds and cotton. We found that $S$. bicolor had no major effect on the plant height of the cotton or the weeds (Fig. 2). However, it did have an effect on the dry masses of shoots and roots in Cenchrus echinatus and Cynodon dactylon (Fig. 3).

In the cotton and Sorghum bicolor treatment, we found no phytotoxic effect on dry mass. Instead, we observed increases of $122 \%$ and $141 \%$ in the mass of cotton canopy and roots, respectively. Cheema et al. (2003) also reported a beneficial effect of intercropping $S$. bicolor with wheat. The authors carried out a study involving the control of weeds and wheat competition by foliar application of $S$. bicolor water extract (12 $\mathrm{L} \mathrm{ha}^{-1}$ at 30 and 40 days after sowing) and observed a $33-53 \%$ reduction in weed biomass, together with a $7-14 \%$ increase in wheat yield. These results seem to be associated with the density of S. bicolor in management with other cultures. Hallak et al. (1999) found anatomical changes in beans (Phaseolus vulgaris L.) grown in the presence of root exudates of S. bicolor at 0.10 and $0.15 \mathrm{mM}$. The authors observed a reduction in the number of cell layers, thickening of the cellulose portions of the collenchyma, and deformation of vessel elements. In a similar study, Souza et al. (1999) found sorgoleone to be phytotoxic to wheat, beans, soy, and pigweed, even resulting in death, at $0.10 \mathrm{mM}$.

Although Sorghum bicolor is considered to be a highly allelopathic species, its toxic effect is not the same for other crops, because it depends on many factors, such as genotype concentration, plant density, fertility, and soil moisture (Rice, 1984; Kruse et al. 2000; Yang et al. 2004). However, the efficacy of control against some weeds might not occur immediately, as does that of commercial herbicides, but could build over time, as with most natural products (Belz 2007). Netzley et al. (1988) reported that the concentration of sorgoleone exuded into the soil from S. bicolor roots can reach 10-100 $\mu \mathrm{M}$. According to Czarnota et al. (2001), the post-emergence application of sorgoleone inhibits the

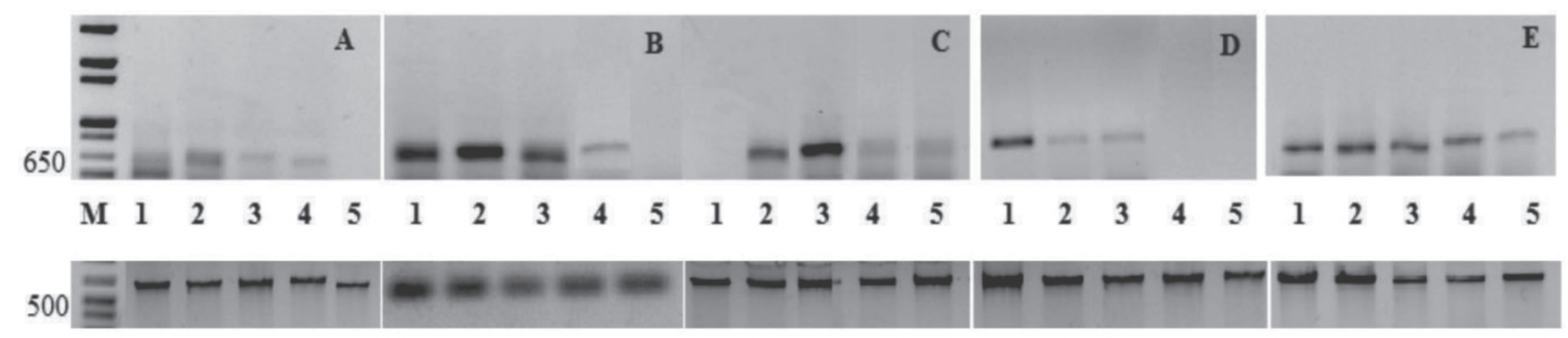

Figure 1. Temporal expression in Sorghum bicolor accessions: of the sorl gene (upper gel); and of $\beta$-actin (lower gel).

A - cultivar IPA 467-4-2; B - cultivar IPA 7301011; C - cultivar IPA 4202; D - cultivar CNB 9040; E - cultivar Sudan; M - molecular weight marker (1-kb DNA ladder); 1, 2, 3, 4, and 5 - rootlets collected at 5, 10, 15, 20, and 30 days after emergence, respectively.

Values on the left indicate the number of base pairs. 


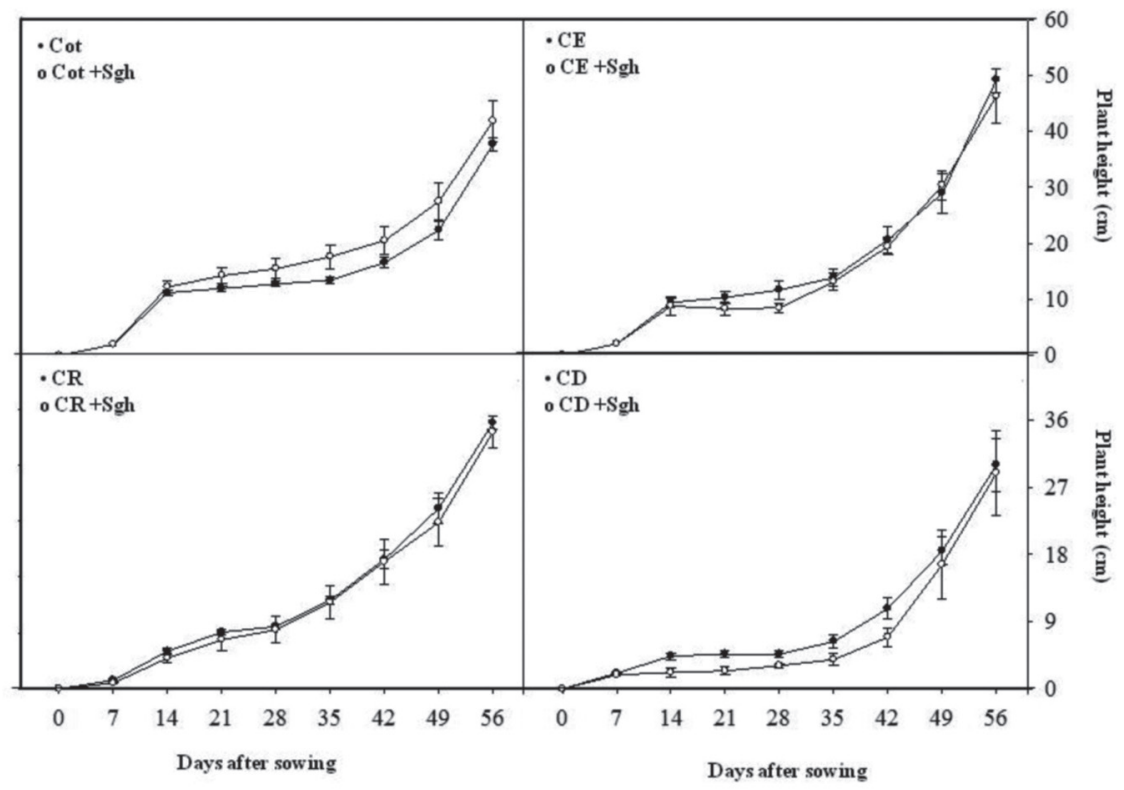

Figure 2. Plant heights of Sorghum bicolor, cotton and three weeds in single-cropping and intercropping treatments.

Cot - cotton; CE - Cenchrus echinatus; CR - Cyperus rotundus; CD - Cynodon dactylon; Sgh - Sorghum.

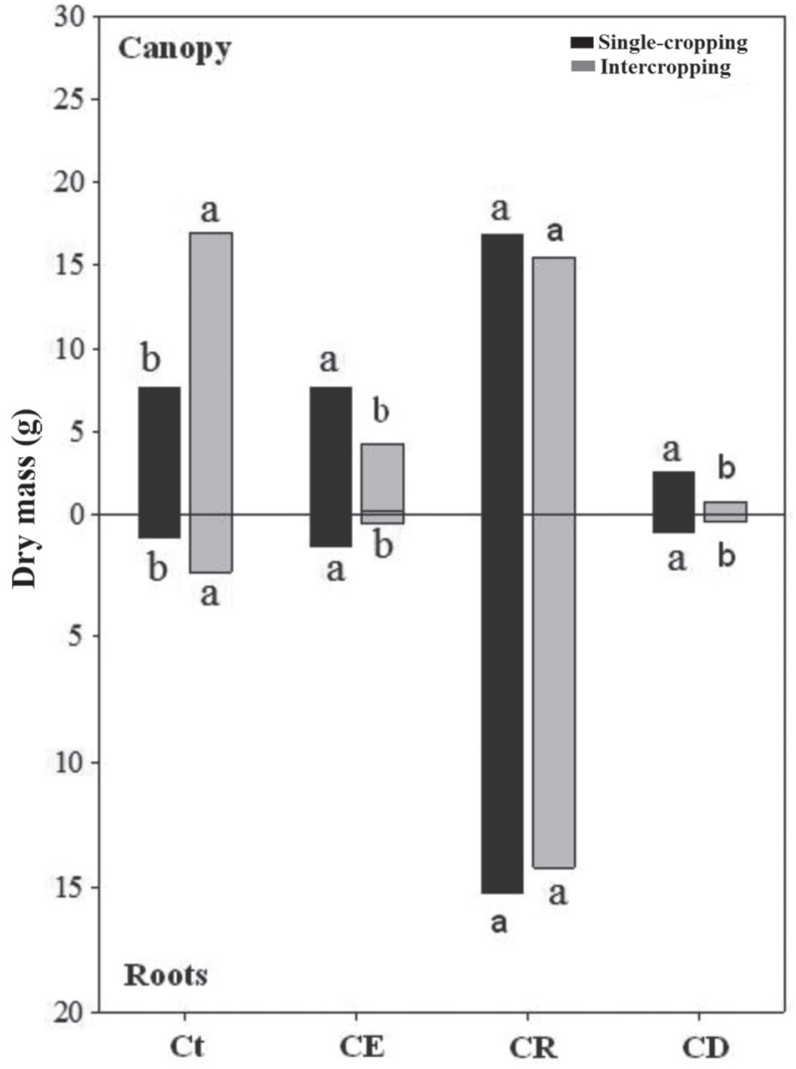

Figure 3. Dry biomass of Sorghum bicolor, cotton and three weeds in single-cropping and intercropping treatments.

Cot - cotton; CE - Cenchrus echinatus; CR - Cyperus rotundus; CD - Cynodon dactylon.

Different letters indicate significant differences at $p<0.05$ (Tukey's test). growth of various weeds, especially broad-leaf weeds, at the same concentration as the synthetic herbicide atrazine (0.6 kg a.i. ha $\left.{ }^{-1}\right)$. Weston \& Czarnota (2001) also showed S. bicolor toxicity in pre-emergent small-seeded weeds.

The results of the present study confirm the findings of Wu et al. (1999), who showed that there is genetic variability in sorgoleone production among Sorghum accessions at the intraspecific and interspecific levels. At the molecular level, Yang et al. (2004) demonstrated such variability from the amino acid sequence of the SOR1 protein among species of tomato, potato, tobacco, sesame, beans, rice, and sorghum. These findings open a range of opportunities for genetic improvement of the germplasm containing this gene, in order to select crops with high allelopathic ability. Despite the great benefit of crops with allelopathic properties for the agroecological management of weeds, scientists emphasize the need to understand the genetic control of allelopathy (Baerson et al. 2008b; Albuquerque et al. 2010).

On the basis of our results, not only those related to the sor 1 expression in the roots of the different Sorghum bicolor accessions but also those related to the inhibitory effect of the Sudan cultivar on the biomass production of two major weeds, we suggest a pyramid breeding scheme involving the Sudan and IPA 7301011 cultivars with other high-yield top lines, in order to generate progenies for further use in single cropping or intercropping agroecological management. It should be borne in mind that, prior to intercropping management, the absence of an allelopathic effect on the other main crop should be verified, in order to ensure that S. bicolor will be phytotoxic only to the weeds. 


\section{Acknowledgments}

This study received financial support from the following Brazilian agencies: the Financiadora de Estudos e Projetos (FINEP, Financing Agency for Studies and Projects); the Ministério da Ciência e Tecnologia (MCT, Ministry of Science and Technology); the Conselho Nacional de Desenvolvimento Científico e Tecnológico (CNPq, National Council for Scientific and Technological Development); the Ministério da Educação (MEC, Ministry of Education); the Coordenação de Aperfeiçoamento de Pessoal de Nível Superior (CAPES, Office for the Advancement of Higher Education); the Fundo Setorial do Agronegócio (CT-AGRO, Agribusiness Sector Fund) and Fundo Setorial de Recursos Hídricos (CT-HIDRO, Water Resources Sector Fund) of the Fundo Nacional de Desenvolvimento Cientifico e Tecnológico (FNDCT, National Fund for Scientific and Technological Development); the Fundações de Amparo à Pesquisa (FAPS, Foundations for the Support of Research); and the Empresa Brasileira de Pesquisa Agropecuária (Embrapa, Brazilian Agency for Agricultural Research).

\section{References}

Albuquerque, M.B.; Santos, R.C.; Lima, L.M.; Melo-Filho P.A.; Nogueira, R.J.M.C.; Câmara, C.A.G.; \& Ramos, A.R. 2010. Allelopathy, an alternative tool to improve cropping systems. A review. Agronomy for Sustainable Development 31(2): 379-395.

Baerson, S.R.; Rimando, A.M. \& Pan, Z. 2008a. Probing allelochemical biosynthesis in sorghum root hairs. Plant Signaling \& Behavior 3(9): 667-670.

Baerson, S.R.; Dayan, F.E.; Rimando, A.M.; Nanayakkara, N.P.D.; Liu, C.J.; Schroder, J.; Fishbein, M.; Pan, Z.; Kagan, I.A.; Pratt, L.H.M.; Pratt, M.C. \& Duke, S.O. 2008b. A functional genomics investigation of allelochemical biosynthesis in Sorghum bicolor root hairs. The Journal of Biological Chemistry 283 (6): 3231-3247.

Barbosa, L.C.A.; Pereira, U.A.; Maltha, C.R.A.; Teixeira, R.R.; Valente, V.M.M.; Ferreira, J.R.O.; Costa-Lotufo, L.V.; Moraes, M.O. \& Pessoa, C. 2010. Synthesis and biological evaluation of 2,5-Bis(alkylamino)-1,4benzoquinones. Molecules 15: 5629-5643.

Belz, R.G. 2007. Allelopathy in crop/weed interactions - an update. Pest Management Science 63: 308-326.

Bertin, C.; Yang, X. \& Weston, L.A. 2003. The role of root exudates and allelochemicals in the rhizosphere. Plant Soil 256: 67-83.

Bolonhezi, D.; Godoy, I.J. \& Santos, R.C. 2005. Manejo Cultural do Amendoim. Pp. 193-244. In: Santos, RC. O Agronegócio do amendoim no Brasil. Campina Grande, Embrapa.

Buchanan, B.B.; Gruissem, W. \& Jones, R.L. 2000. Biochemistry and molecular biology of plants. Rockville, American Society of Plant Physiologists.

Cheema, Z.A., M. Luqman and A. Khaliq. 1997. Use of allelopathic extracts of sorghum and sunflower herbage for weed control in wheat. Journal of Animal and Plant Sciences 7: 91-93.

Cheema, Z.A., A. Khaliq and M. Mubeen. 2003. Response of wheat and winter weeds to foliar application of different plant water extracts. Pakistan Journal of Weed Science Research 9: 89-97.

Correia, N.M. \& Durigan, J.C. 2007. Seletividade de diferentes herbicidas à base de glyphosate a soja RR. Planta Daninha 25 (2): 375-379.

Cruz, C.D. 2006. Programa Genes: aplicativo computacional em genética e estatística. Viçosa, Editora UFV.

Czarnota, M.A.; Paul, R.N.; Dayan, F.E.; Nimbal, C.I. \& Weston, L.A. 2001. Mode of Action, Localization of Production, Chemical Nature, and Activity of Sorgoleone: A Potent PSII Inhibitor in Sorghum spp. Root Exudates. Weed Technology 15: 813-825.
Dayan, F.E.; Kagan, I.A. \& Rimando, A.M. 2003. Elucidation of the biosynthetic pathway of the allelochemical sorgoleone using retrobiosynthetic NMR analysis. The Journal Biological Chemistry 278(31): 28607-28611.

Dayan, F.E. 2006. Factors modulating the levels of the allelochemical sorgoleone in Sorghum bicolor. Planta 224: 339-346.

Dayan, F.E.; Watson, S.B. \& Nanayakkara, N.P.D. 2007. Biosynthesis of lipid resorcinols and benzoquinones in isolated secretory plant root hairs. Journal of Experimental Botany 58(12): 6263-3272.

Einhellig, F. A.; Souza, I. F. 1992. Phytotoxicity of sorgoleone found in grain sorghum root exudates. Journal of Chemical Ecology 18: 1-11.

Forney, D.R. \& Foy, C.L. 1985. Phytotoxicity of products from rhizospheres of a sorghum-sudangrass hybrid (Sorghum bicolor $\mathrm{x}$ Sorghum sudanense). Weed Science 33(5): 597-604.

Hallak, A.M.G.; Davide, L.C.; Gavilanes, M.L. \& Souza, I.F. 1999. Efeito de exsudatos de sorgo (Sorghum bicolor L.) sobre a divisão celular e anatomia de plântulas de feijão (Phaseolus vulgaris L.). Ciência e Agrotecnologia 23(2): 317-322.

Hejl, A.M. \& Koster, K.L. 2004. The allelochemical sorgoleone inhibits root $\mathrm{H}^{+}$-ATPase and water uptake. Journal of Chemical Ecology 30(11): 2181-2191.

Imura, O.; Shi, K.; Limura, K. \& Takamizo, T. 2011. Assessing the effects of cultivating genetically modified glyphosate-tolerant varieties of soybeans (Glycine max (L.) Merr.) on populations of field arthropods. Environmental Biosafety Research 9(2): 101-112.

Kruse, M.; Strandberg, M. \& Strandberg, B. 2000. Ecological effects of allelopathic plants. A review. Silkeborg, Denmark, Department of Terrestrial Ecology, Rep. n. 315

Marchi, G.; Marchi, E.C.S.; Wang, G. \& Mcgiffen, M. 2008. Effect of age of a sorghum-sudangrass hybrid on its allelopathic action. Planta Daninha 26(4): 707-716.

Meazza, G.; Scheffler, B.E.; Tellez, M.R.; Rimando, A.M.; Nanayakkara, N.P.D.; Khan, I.A.; Abourashed, E.A.; Romagni, J.G.; Duke, S.O. \& Dayan, F.E. 2002. The inhibitory activity of natural products on plant p-hydroxyphenylpyruvate dioxygenase. Phytochemistry 60: 281-288.

Melo, R.M.C.A.; Melo Filho, P.A.; Camara, M.P.S.; Lma, W.G. \& Santos, R.C. 2013. Preventive control of cotton ramulosis using clove oil at low concentration. International Journal of Agricultural Science Research 2(3): 60-66.

Netzly, D.H. \& Butler, L.G. 1986. Roots of sorghum exude hydrophobic droplets containing biologically active components Crop Science 26: 775-778.

Netzly, D. H.; Riopel, J. L.; Ejeta, G.; Butler, L. G. 1988. Germination stimulants of witchweed (Striga asiatica) from hydrophobic root exudates of sorghum (Sorghum bicolor). Weed Science 36: 441-446.

Neves, R. 2005. Potencial alelopático da cultura da canola (Brassica napus L. var. oleifera) na supressão de picão-preto (Bidens sp.) e soja. Passo Fundo, Universidade de Passo Fundo.

Nimbal, C.I.; Yerkes, C.N.; Weston, L.A. \& Weller, S.C. 1996. Herbicidal activity and site of action of the natural product sorgoleone. Pesticide Biochemistry and Physiology 54: 73-83.

Pan, Z.; Rimando, A.M.; Baerson, S.R.; Fishbein, M. \& Duke, S.O. 2007. Functional characterization of desaturases involved in the formation of the terminal double bond of an unusual $16: 3 \Delta^{9,12,15}$ fatty acid isolated from Sorghum bicolor root hairs. The Journal of Biological Chemistry 282(7): 4326-4335.

Parker, R.G.; Alan, C.Y. \& David, L.J. 2005. Comparison of glyphosate products in glyphosate-resistant cotton (Gossypium hirsutum) and corn (Zea mays). Weed Technology 19(4): 796-802.

Rice, E.L. 1984. Allelopathy, 3ed., Orlando, Academy Press.

Roth, C.M.; Shroyer, P. \& Paulsen, G.M. 2000. Allelopathy of sorghum on wheat under several tillage systems. Agronomy Journal 92(5): 855-860.

Singh, H.P.; Batish, D.R. \& Kohli, R.K. 2003. Allelopathic Interactions and Allelochemicals: New Possibilities for Sustainable Weed Management. Critical Reviews in Plant Sciences 22: 239-311.

Souza Filho, A.P.S.; Santos, R.A.; Santos, L.S.; Guilhon, G.M.P.; Santos, A.S.; Arruda, M.S.P.; Muller, A.H. \& Arruda, A.C. 2006. Potencial alelopático de Myrcia guianensis. Planta Daninha 24(4): 649-656. 
Roseane Cavalcanti dos Santos, Gabriela de Morais Guerra Ferraz, Manoel Bandeira de Albuquerque,

Liziane Maria Lima, Péricles de Albuquerque Melo Filho and Alessandra de Rezende Ramos

Souza, C.N. de; Souza, I.F. de; Pasqual, M. 1999. Extração e ação de sorgoleone sobre o crescimento de plantas. Ciência e Agrotecnologia 23(2): 331-338.

Trezzi, M.M. \& Vidal, R.A. 2004. Potencial de utilização de coberturas vegetais de sorgo e milheto na supressão de plantas daninhas em condições de campo. Planta Daninha 22(2): 217-223.

Weston, L.A. \& Czarnota, M.A. 2001. Activity and persistence of sorgoleone, a long-chain hydroquinone produced by Sorghum bicolor. Journal of Crop Production 4: 363-377.
Weston, L.A. \& Duke, S.O. 2003. Weed and crop allelopathy. Critical Reviews in Plant Sciences 22: 367-389.

Wu, H.; Pratley, H.; Lemerle, D. \& Haig, T. 1999. Crop cultivars with allelopathic capability. Weed Research 39:171-180.

Yang, X.; Scheffler, B.E. \& Weston, L.A. 2004. Sor1, a gene associated with bioherbicide production in sorghum root hairs. Journal of Experimental Botany 55(406): 2251-2259. 